\title{
Analysis of virion associated host proteins in vesicular stomatitis virus using a proteomics approach Megan Moerdyk-Schauwecker ${ }^{1}$, Sun-Il Hwang ${ }^{2}$ and Valery Z Grdzelishvili*1
}

Address: ${ }^{1}$ Department of Biology, University of North Carolina at Charlotte, Charlotte, NC 28223, USA and ${ }^{2}$ Cannon Research Center, Carolinas Medical Center, Charlotte, NC 28203, USA

Email: Megan Moerdyk-Schauwecker - mmoerdyk@uncc.edu; Sun-Il Hwang - Sunil.Hwang@carolinashealthcare.org; Valery Z Grdzelishvili* - vzgrdzel@uncc.edu

* Corresponding author

Published: 12 October 2009

Virology Journal 2009, 6:166 doi:10.1186/1743-422X-6-166

This article is available from: http://www.virologyj.com/content/6/I/166

(C) 2009 Moerdyk-Schauwecker et al; licensee BioMed Central Ltd.

This is an Open Access article distributed under the terms of the Creative Commons Attribution License (http://creativecommons.org/licenses/by/2.0), which permits unrestricted use, distribution, and reproduction in any medium, provided the original work is properly cited.
Received: 20 August 2009

Accepted: 12 October 2009

\begin{abstract}
Background: Vesicular stomatitis virus (VSV) is the prototypic rhabdovirus and the best studied member of the order Mononegavirales. There is now compelling evidence that enveloped virions released from infected cells carry numerous host (cellular) proteins some of which may play an important role in viral replication. Although several cellular proteins have been previously shown to be incorporated into VSV virions, no systematic study has been done to reveal the host protein composition for virions of VSV or any other member of Mononegavirales.
\end{abstract}

Results: Here we used a proteomics approach to identify cellular proteins within purified VSV virions, thereby creating a "snapshot" of one stage of virus/host interaction that can guide future experiments aimed at understanding molecular mechanisms of virus-cell interactions. Highly purified preparations of VSV virions from three different cell lines of human, mouse and hamster origin were analyzed for the presence of cellular proteins using mass spectrometry. We have successfully confirmed the presence of several previously-identified cellular proteins within VSV virions and identified a number of additional proteins likely to also be present within the virions. In total, sixty-four cellular proteins were identified, of which nine were found in multiple preparations. A combination of immunoblotting and proteinase $\mathrm{K}$ protection assay was used to verify the presence of several of these proteins (integrin $\beta \mathrm{I}$, heat shock protein $90 \mathrm{kDa}$, heat shock cognate 7l kDa protein, annexin 2, elongation factor la) within the virions.

Conclusion: This is, to our knowledge, the first systematic study of the host protein composition for virions of VSV or any other member of the order Mononegavirales. Future experiments are needed to determine which of the identified proteins have an interaction with VSV and whether these interactions are beneficial, neutral or antiviral with respect to VSV replication. Identification of host proteins-virus interactions beneficial for virus would be particularly exciting as they can provide new ways to combat viral infections via control of host components.

\section{Background}

The order Mononegavirales contains four families (Rhabdoviridae, Paramyxoviridae, Filoviridae and Bornaviridae), which include many lethal human pathogens (e.g. rabies, Ebola, and Hendra viruses); highly prevalent human pathogens, such as the respiratory syncytial and parainflu- 
enza viruses; potential ethological agents of some neurobehavioral abnormalities and psychiatric disorders in humans (Borna disease virus); as well as viruses with a major economic impact on the poultry and cattle industries (e.g. Newcastle disease virus and rinderpest virus). All members of this order share a similar genome organization and common mechanisms of genome replication and gene expression, and, as with other RNA viruses with limited coding capacity, they exploit cellular proteins and pathways to facilitate many aspects of their replication cycle [1-3]. Identification of host-virus interactions can provide new insights into viral biology and developing new ways to combat viral infections via control of host components.

Vesicular stomatitis virus (VSV) is the best studied member of Mononegavirales and the prototypic rhabdovirus. There is now compelling evidence that enveloped virions (including members of Mononegavirales) released from infected cells carry numerous host (cellular) proteins some of which may play an important role in viral replication [4]. Several cellular proteins have been previously shown to be incorporated into VSV virions including tubulin [5], cyclophilin A [6], translation elongation factor 1 alpha (EF1a) [7], RNA guanylyltransferase [8], casein kinase II [9] and heat shock cognate $71 \mathrm{kDa}$ protein (Hsc70, also known as HSPA8) [10]. However, to the best of our knowledge, no systematic study has been done to reveal the host protein composition for virions of VSV or any other member of Mononegavirales.

A proteomics approach utilizing mass spectrometry (MS) has been used to successfully identify cellular proteins in a number of enveloped viruses including poxviruses [1113], herpesviruses [14-20], orthomyxoviruses [21], coronaviruses [22], and retroviruses [23-25]. Here we attempted the same strategy to identify cellular proteins within purified VSV virions, thereby creating a "snapshot" of one stage of virus/host interaction that can guide future experiments aimed at understanding molecular mechanisms of virus-cell interactions. Using this approach, we confirmed the presence of several previously-identified cellular proteins within VSV virions and identified a number of additional proteins.

\section{Results}

\section{Purification of VSV from different cell types}

Several cell lines [including BHK21 (hamster), HeLa (human), A549 (human), HEp2 (human), MIA PaCa (human), 4T1 (mouse), 3T3 (mouse), 3T10 (mouse), 2H11 (mouse), MOVAS (mouse) and Vero (green monkey)] were tested for their ability to support robust replication of VSV and produce high titers of virus, which is required for successful purification and subsequent proteomic analysis. Based on this analysis (data not shown), we selected three cell lines, capable of producing the high VSV titers: BHK21 (baby hamster kidney cells), 4T1 (mouse mammary tumor cells) and A549 (human lung carcinoma cells) (Fig. 1). BHK21 has been extensively used as a standard cell line for growing VSV. A549 and 4T1 cells also supported suitable viral replication although to lower titers than BHK21 cells (Fig. 2B). The use of different cell lines allowed us to compare viral host protein content across species and cell types. In addition, the A549 and $4 \mathrm{~T} 1$ cell lines were included to allow identification of cellular proteins potentially lacking sufficient homology to human or mouse proteins to be recognized from a hamster source (BHK21).

To grow and purify viruses, BHK21 cells were infected with VSV HR1 (Indiana serotype), while A549 and 4T1 cells were infected with VSV wild type (VSV-wt, Indiana serotype). VSV HR1 is a well characterized mRNA cap methylation defective VSV (Indiana serotype) host-range (hr) mutant which has a delay in replication but achieves wild type titers in BHK21 [26-29]. VSV HR1 was chosen for BHK21 infection as the milder cytopathic effect in BHK21 cells compared to VSV-wt aid exclusion of cellular debris (data not shown). However, VSV-wt was used for

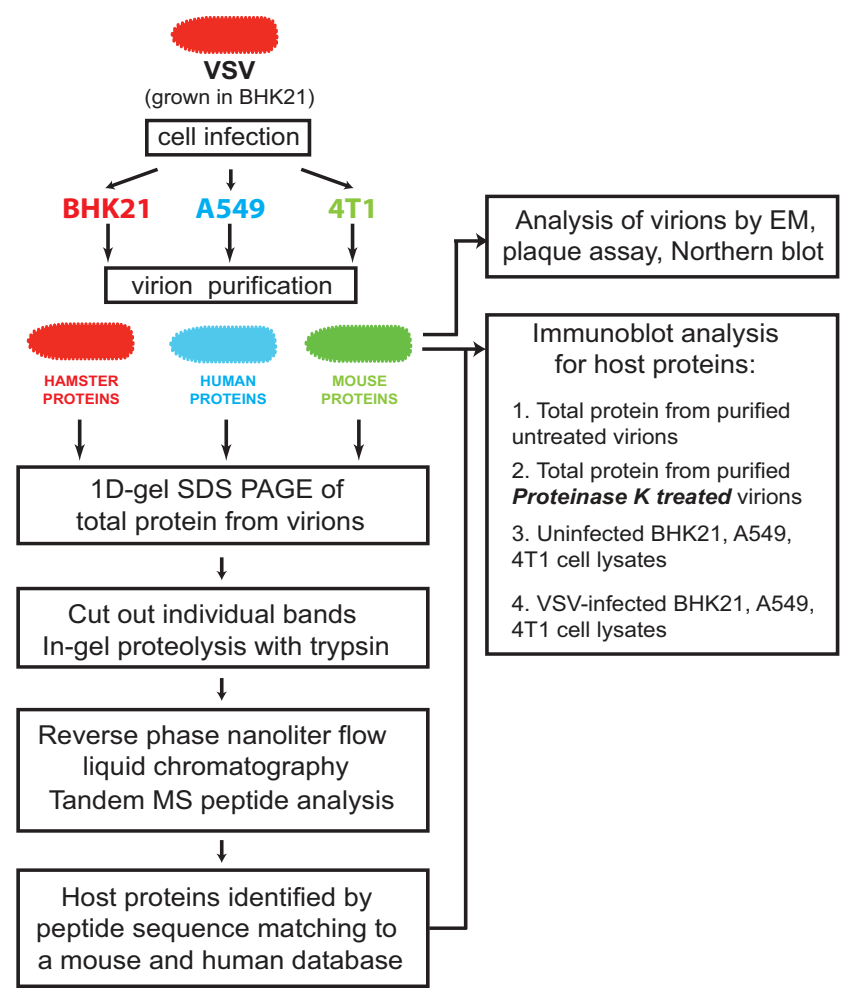

Figure I

Overview of the experimental procedure used in this study. 
A.

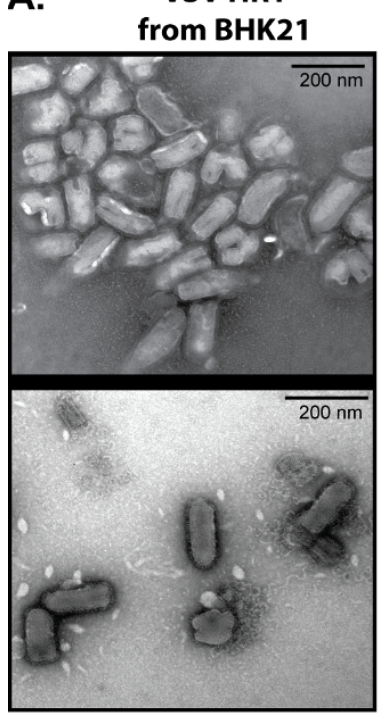

VSV HR1

from BHK21

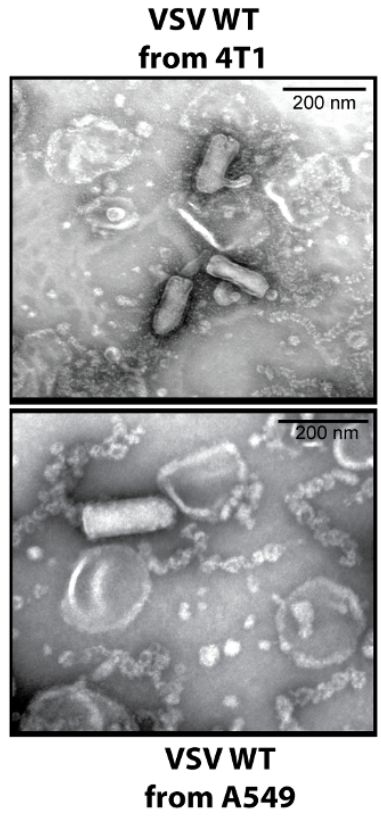

from A549

B.

\begin{tabular}{|c|c|c|c|}
\hline VIRIONS & $\begin{array}{c}\text { Infectivity } \\
\mathrm{PFU} / \mathrm{ml}\end{array}$ & $\begin{array}{c}\text { Infectivity } \\
\mathrm{PFU} / \mu \mathrm{g}\end{array}$ & $\begin{array}{c}\text { Protein } \\
\text { concentration } \\
\mathrm{mg} / \mathrm{ml}\end{array}$ \\
\hline $\begin{array}{c}\text { VSV HR1 } \\
\text { from BHK21 }\end{array}$ & $1.8 \times 10^{11}$ & $2.4 \times 10^{7}$ & 7.4 \\
\hline $\begin{array}{c}\text { VSV WT } \\
\text { from 4T1 }\end{array}$ & $1.4 \times 10^{10}$ & $9.4 \times 10^{5}$ & 14.8 \\
\hline $\begin{array}{c}\text { VSV WT } \\
\text { from A549 }\end{array}$ & $2.2 \times 10^{9}$ & $6.3 \times 10^{5}$ & 3.5 \\
\hline
\end{tabular}

C.

Total RNA, Northern blot

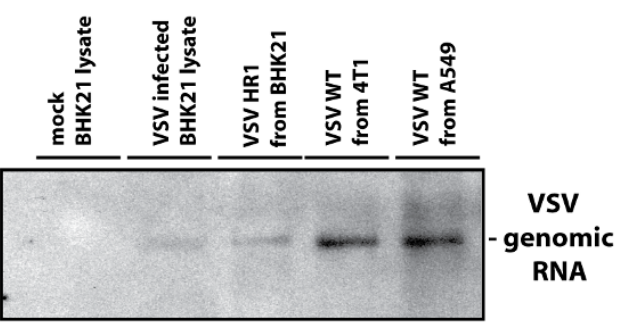

D.

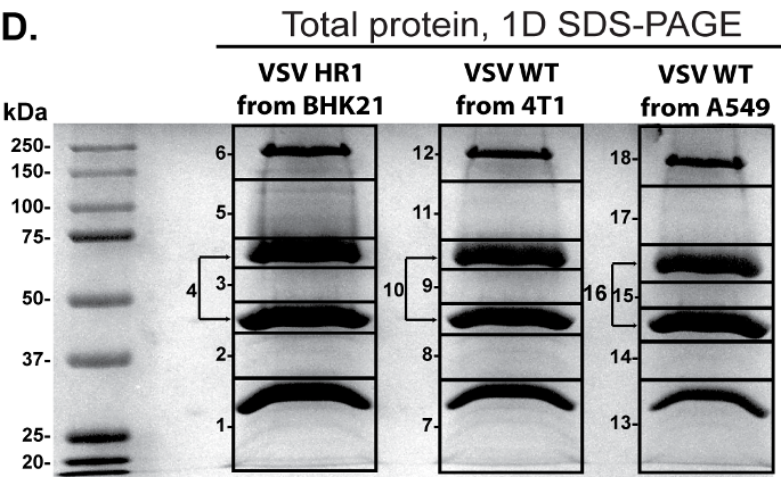

Figure 2

\section{Figure 2}

Characterization of purified VSV virion preparations.

(A) Electron micrographs of the purified virion preparations from BHK2I (two different fields are shown), 4TI and A549. Virions were absorbed to carbon-formvar coated grids and negatively stained with $2 \%$ uranyl acetate. (B) Infectivity $(\mathrm{PFU} / \mathrm{ml})$ of purified virions shown in (A) was calculated by standard plaque assay on BHK2I cells. Total protein concentration of these preparations was determined using a Bradford assay, and infectivity per total protein (PFU/ $/ \mathrm{gg}$ ) was calculated based on these two values. (C) Total RNA was extracted from uninfected (mock) or infected BHK2I cells or from purified virion samples containing $25 \mu \mathrm{g}$ of protein, and analyzed by Northern blotting. RNA was separated on a I.5\% agarose-formaldehyde gel, transferred to a nylon membrane and detected using a probe complimentary to the $3^{\prime}$ end of VSV genome. (D) $50 \mu \mathrm{g}$ of total protein from each purified virion preparation was separated on a $10 \%$ SDSPAGE gel, and stained with Coomassie Brilliant Blue R250. Numbered boxes indicate the gel segments cut out and analyzed by mass spectrometry.

infection of A549 and 4T1 cells as replication of VSV HR1 was more inhibited in these two cell lines than in BHK21 due to its host-range growth phenotype (data not shown) and the cytopathic effect caused by VSV-wt in these cells was not as rapid or severe as seen with BHK21.

Virus containing media was collected at 20-28 hours (h) post infection (p.i.) when most cells were infected but significant cell detachment had not yet occurred (to maximize exclusion of cellular debris), and virions were purified using a discontinuous sucrose gradient purification protocol as described in the Materials and methods section. Initial concentration of virus by polyethylene glycol precipitation [30] as well as the use of continuous sucrose [30], cesium chloride [31], and iodixanol gradients [32] were also tried without significant improvement in sample infectivity or purity (data not shown).

Virion samples were examined by transmission electron microscopy (EM) for the presence of nonviral structures and to assess virion integrity. As shown in Figure 2A, the sample derived from BHK21 cells was primarily composed of particles readily recognizable as VSV although the possibility of some cellular contaminants cannot be ruled out. In addition to standard "bullet shaped" particles, there were also large numbers of "bent" particles where the virion appears to have been broken in half. These bent particles have been shown to be a substantial component of at least some VSV preparations and are infectious [31]. The presence of other "irregular" particles is consistent with previous studies demonstrating that VSV virions can easily undergo morphological changes 
when processed for visualization by EM $[33,34]$. In contrast to the BHK21 preparation, the virion preparations from A549 and 4T-1 showed fewer intact virus particles, and a large number of unwound nucleocapids could be seen (Fig. 2A). Some of the membranous structures present may represent the viral membranes dissociated from the nucleocapsids, although the possibility of them being cellular vesicles cannot be ruled out [35]. Consistent with the differences observed by EM (Fig. 2A) was the variation in the number of infectious particles per $\mu \mathrm{g}$ of total protein (Fig. 2B). However, when equal quantities of total protein were separated on a $10 \%$ SDS-PAGE gel and visualized by Coomassie staining (Fig. 2D) or analyzed by immunoblotting against VSV proteins (data not shown), the quantity and distribution of the viral proteins was similar in all samples as were the intensity and number of minor bands representing cellular or degraded viral proteins. Additionally, when total RNA extracted from samples containing equal quantities of protein was analyzed by Northern blotting using a probe complimentary to the $3^{\prime}$ end of VSV genome, greater numbers of viral genomes were recovered from purified virus samples from 4T1 and A549 than from BHK21 cells (Fig. 2C). Smaller products representing defecting interfering genomic RNAs were not detected in any sample, even upon overexposure of the membrane (data not shown). This supports our hypothesis that the filament structures seen in Figure 2A for A549 and $4 \mathrm{~T} 1$ virion preparations are unwound VSV nucleocapids containing viral genomic RNA. That these filaments are not cellular nucleic acids is also supported by the lack of detection of any histone or ribosomal proteins in the A549 and 4T1 samples by MS (Table 1). Together, the Northern blot (Fig. 2C) and Coomassie staining (Fig. 2D) data suggest the observed visual differences between samples (Fig. 2A) are at least in part due to differences in particle stability/infectivity rather than simply sample purity.

\section{Identification of virion associated proteins using proteomic approach}

For MS analysis, $50 \mu \mathrm{g}$ of total protein was separated on a 1-D SDS-PAGE gel, stained with Coomassie Brilliant Blue R250 and gel bands were cut out for analysis as indicated in Figure 2D. Gel pieces were subjected to in-gel trypsin digestion and the resulting peptides were extracted from the gel matrix, separated using reverse-phase nano-liquid chromatography, analyzed by tandem MS [36], and searched against human and mouse databases (concatenated with a VSV protein database), as described in the Materials and methods section. All five VSV proteins were identified by this analysis, as well as 64 cellular proteins (Table 1) plus keratins (not shown in Table 1). Of the 64 proteins, nine were identified in more than one sample. Five proteins [tubulin alpha, annexin A2, EF1a, ubiquitin and integrin $\beta 1$ ] were identified in all three samples while tubulin beta, cytoplasmic actin and translation elongation factor 2 were identified only in the BHK21 and 4T1 derived virion preparations; and transferin receptor protein 1 was identified only in the 4T1 and A549 derived preparations.

\section{Confirmation of virion incorporation for several cellular proteins}

Several proteins [integrin $\beta 1$, heat shock protein $90 \mathrm{kDa}$ (Hsp90), Hsc70, annexin 2, EF1a] identified by MS were picked for analysis by immunoblotting to confirm their presence in the virion preparations. $50 \mu \mathrm{g}$ of purified virions and $10 \mu \mathrm{g}$ of cellular lysate prepared from mock infected cells or cells infected with VSV-wt harvested at 18 h p.i. were separated on SDS-PAGE gels and analyzed by immunoblotting (Fig. 3B), as described in the Materials and methods section.

To determine whether these selected cellular proteins were incorporated within virions, a portion of purified virions from BHK21 and 4T1 cells were treated with proteinase $\mathrm{K}$ (ProK). ProK treatment degrades any proteins associated with the exterior surface of the virion as well as the exposed portion(s) of any membrane proteins, while the viral envelope excludes ProK from the interior of the virion, thereby protecting proteins incorporated into the virion $[37,38]$. A portion of the treated virions from 4T1 cells were additionally purified by centrifugation through a $20 \%$ sucrose cushion. This process removed the proteinase and cleaved peptides and aided removal of any residual contaminating vesicles as proteinase treatment would decrease the density of vesicles to a greater extent than the virions [39]. Due to insufficient quantities of purified virions from the preparations analyzed by MS, we were unable to conduct all treatments with preparations from all three cell lines.

As seen in Figures 3A and 3B, ProK treatment resulted in the almost complete removal of the viral glycoprotein (G). However, residual quantities of $G$ could be visualized by immunoblotting with anti-VSV antibodies, indicating the process was not $100 \%$ efficient (data not shown). In contrast, substantial amounts of the viral matrix (M), nucleocapsid (N), phosphoprotein (P) and large polymerase (L) proteins were protected from ProK activity by the viral membrane, although we estimate that about $50 \%$ of these proteins were lost from the BHK21 derived virions during this process, about $70 \%$ from the $4 \mathrm{~T} 1$ derived virions and about $90 \%$ from the ProK treated and additionally purified $4 \mathrm{~T} 1$ derived virions. This loss of presumably membrane-protected proteins was likely due to physical disruption of the virion membrane, and the differences in protein loss were consistent with the varying degrees of virion disruption observed by EM (Fig. 2A). Due to the high loss of protein from the 4T1 derived sample, we were unable to obtain sufficiently concentrated 
Table I: Cellular proteins identified in purified virion preparations following I-D SDS-PAGE and LC-MS/MS

\begin{tabular}{|c|c|c|c|c|c|c|c|}
\hline \multirow[b]{2}{*}{ Protein name } & \multirow[b]{2}{*}{ Taxonomy a } & \multirow[b]{2}{*}{$\begin{array}{c}\text { Accession } \\
\text { No. }{ }^{b}\end{array}$} & \multirow[b]{2}{*}{ Mass (kDa) } & \multicolumn{3}{|c|}{$\begin{array}{c}\text { Gel pieces found in } \mathrm{d} \\
\text { (No. of spectra/No. unique peptides) }\end{array}$} & \multirow[b]{2}{*}{$\begin{array}{l}\text { Other viruses } \\
\text { found in } \mathrm{e}\end{array}$} \\
\hline & & & & BHK & 4TI & A549 & \\
\hline \multirow[t]{2}{*}{ Tubulin alpha } & $\mathrm{H}$ & IPI00|80675 & 50.1 & $3(11 / 9)$ & & & $\begin{array}{l}\text { Influenza [2I], } \\
\text { HCMV [19], VV } \\
{[11,13], \mathrm{HIV}-\mathrm{I}[23] \text {, }} \\
\text { ASFV [58]. }\end{array}$ \\
\hline & $M$ & IPI00| I0753 & 50.1 & $3(11 / 10)$ & $9(2 / 2)$ & $15(2 / 2)$ & \\
\hline \multirow[t]{2}{*}{ Annexin A2 } & $\mathrm{H}$ & IPI004553I5 & 38.6 & $2(8 / 4)$ & $8(4 / 3)$ & 14(3/2) & $\begin{array}{l}\text { Influenza [2I], } \\
\text { HCMV [I9,59], VV } \\
\text { [II], KSHV [20], } \\
\text { HIV-I [23], HSV-I } \\
\text { [I8], AIHV-I [I5]. }\end{array}$ \\
\hline & $M$ & IPI00468203 & 38.5 & $2(12 / 7)$ & $8(5 / 4)$ & $14(2 / 2)$ & \\
\hline \multirow[t]{2}{*}{$\begin{array}{l}\text { Elongation factor I- } \\
\text { alpha }\end{array}$} & $\mathrm{H}$ & IPI000| 4424 & 50.5 & $3(9 / 3)$ & $9(9 / 4)$ & & $\begin{array}{l}\text { HIV-I [23,24,60,6I], } \\
\text { VV [I I,I I ], MCMV } \\
\text { [I7], HCMV [I9], } \\
\text { SARS-CoV [22]. }\end{array}$ \\
\hline & $M$ & IPI00307837 & 50.3 & $3(9 / 3)$ & $9(13 / 6)$ & $15(3 / 2)$ & \\
\hline \multirow[t]{2}{*}{ Ubiquitin } & $\mathrm{H}$ & IPI007| 9280 & 25.8 & $\begin{array}{l}2(6 / 3), 3(4 / 3) \\
4(3 / 2), 5(3 / 2)\end{array}$ & $\begin{array}{l}8(8 / 3), 9(7 / 3) \\
\quad I I(2 / 2)\end{array}$ & $14(3 / 2), 17(2 / 2)$ & $\begin{array}{l}\text { Influenza [2I], HIV- } \\
\text { I }[23,24,62], \text { SIV } \\
{[62], \text { MMLV [25,62], }} \\
\text { VV [II I,45], AcNPV } \\
{[44], \text { ASFV [45]. }}\end{array}$ \\
\hline & M & IPI009230I3 & 26.6 & $\begin{array}{l}2(5 / 2), 3(4 / 3) \\
4(3 / 2), 5(3 / 2)\end{array}$ & $\begin{array}{l}8(7 / 3), 9(6 / 2) \\
10(2 / 2), 11(2 / 2)\end{array}$ & $\begin{array}{l}14(3 / 2), 15(3 / \\
2), 17(2 / 2)\end{array}$ & \\
\hline \multirow[t]{2}{*}{ Integrin beta-I } & $\mathrm{H}$ & IPI002I756I & $91.7 \mathrm{c}$ & $6(2 / 2)$ & $12(3 / 2)$ & $18(6 / 2)$ & $\begin{array}{l}\text { Influenza [2I], HIV- } \\
\text { I [23], MMLV [25]. }\end{array}$ \\
\hline & $M$ & IPI00I 32474 & $88.2^{c}$ & $6(3 / 3)$ & $12(4 / 3)$ & & \\
\hline \multirow[t]{2}{*}{ Tubulin, beta } & $\mathrm{H}$ & IPI000II 654 & 49.7 & $3(11 / 7)$ & $9(3 / 3)$ & & $\begin{array}{l}\text { Influenza [2I], } \\
\text { HCMV [19], EBV } \\
\text { [16], VV [11, I3], } \\
\text { MMLV [25], ASFV } \\
{[58] .}\end{array}$ \\
\hline & $M$ & IPI00|0906I & 49.9 & $3(9 / 6)$ & $9(3 / 3)$ & & \\
\hline \multirow[t]{2}{*}{ Actin, cytoplasmic } & $\mathrm{H}$ & IPI0002| 439 & 41.7 & $4(3 / 2)$ & $8(3 / 3)$ & & $\begin{array}{l}\text { Influenza [2I], } \\
\text { HCMV [19], EBV } \\
\text { [I6], VV [1I,I2,63], } \\
\text { KSHV [20] MMLV } \\
\text { [25], HIV-I [23,39], } \\
\text { MCMV [17], HSV-I } \\
\text { [18], ASFV [58], } \\
\text { AlHV-I [15], SeV } \\
{[48], \text { MV [49], RV }} \\
\text { [50]. }\end{array}$ \\
\hline & $M$ & IPI00I I 0850 & 41.7 & $4(3 / 2)$ & $8(3 / 3)$ & & \\
\hline
\end{tabular}


Table I: Cellular proteins identified in purified virion preparations following I-D SDS-PAGE and LC-MS/MS (Continued)

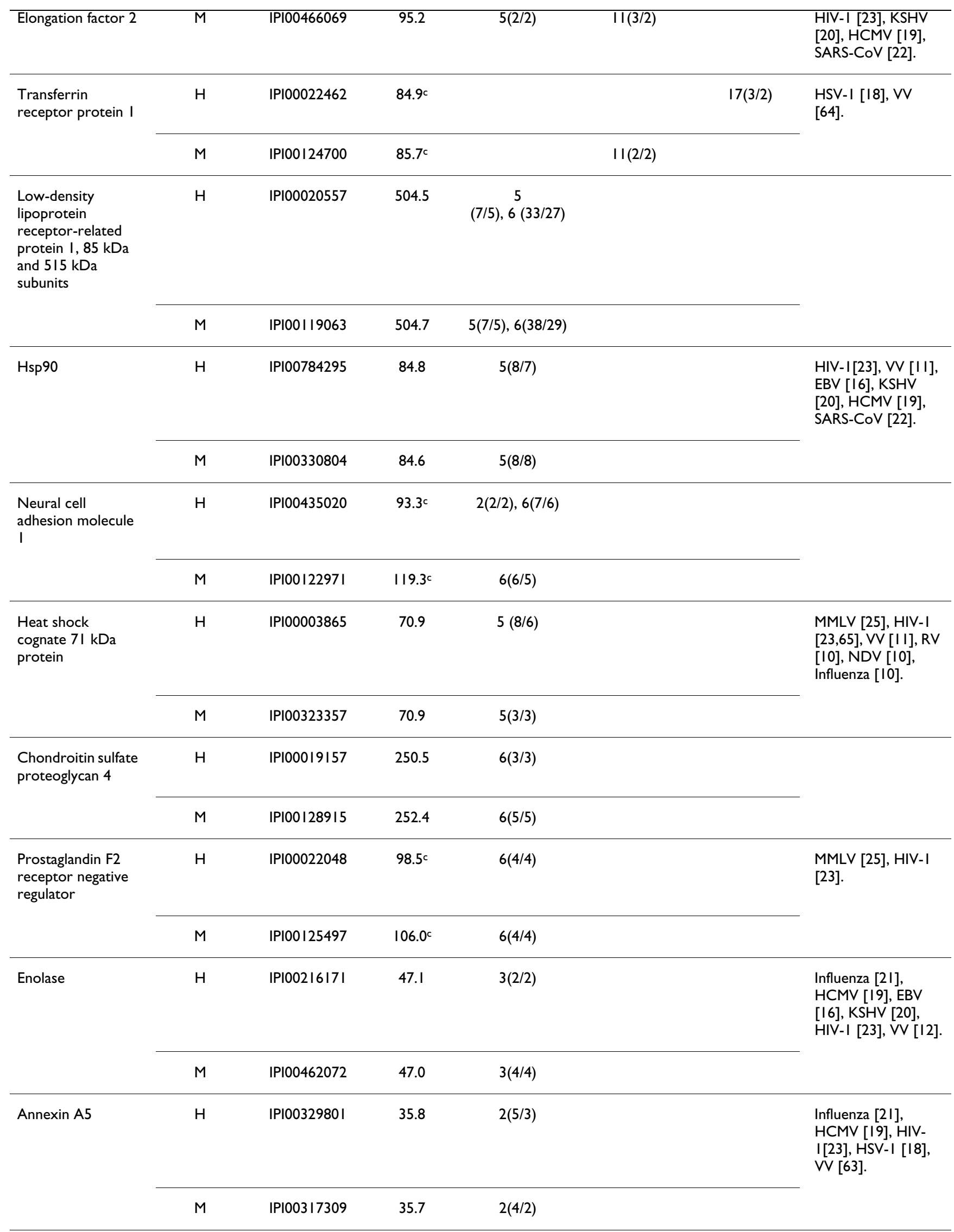


Table I: Cellular proteins identified in purified virion preparations following I-D SDS-PAGE and LC-MS/MS (Continued)

\begin{tabular}{|c|c|c|c|c|c|c|}
\hline \multirow{2}{*}{$\begin{array}{l}\text { Synaptic vesicle } \\
\text { membrane protein } \\
\text { VAT-I homolog }\end{array}$} & \multirow[b]{2}{*}{$M$} & \multirow{2}{*}{$\begin{array}{l}\text { IPI00I56689 } \\
\text { IPI00I } 26072 \\
\end{array}$} & \multirow{2}{*}{$\begin{array}{l}41.9 \\
43.1\end{array}$} & \multirow{2}{*}{$\begin{array}{l}3(4 / 3) \\
3(2 / 2)\end{array}$} & & \\
\hline & & & & & & \\
\hline Annexin A4 & $M$ & IPI00353727 & 35.8 & $2(3 / 2)$ & & Influenza [2I]. \\
\hline \multirow{2}{*}{$\begin{array}{l}\text { ATP synthase alpha } \\
\text { chain, } \\
\text { mitochondrial }\end{array}$} & $\mathrm{H}$ & IPI00440493 & 59.7 & $3(2 / 2)$ & & \\
\hline & $M$ & IPI00| 30280 & 59.7 & $3(2 / 2)$ & & \\
\hline $\begin{array}{l}\text { ATP synthase beta } \\
\text { chain, } \\
\text { mitochondrial }\end{array}$ & M & IPI0046848I & 56.3 & $3(2 / 2)$ & & HIV-I [23], VV [63]. \\
\hline \multirow[t]{2}{*}{ Casein kinase I } & $\mathrm{H}$ & IPI00I67096 & 39.1 & $2(2 / 2)$ & & \\
\hline & M & IPI00330729 & 38.9 & $2(2 / 2)$ & & \\
\hline \multirow[t]{2}{*}{ CD44 antigen } & $\mathrm{H}$ & IPI00297|60 & $39.4^{c}$ & $5(3 / 2)$ & & HIV-I [23]. \\
\hline & $M$ & IPI00223769 & $40.2^{c}$ & $5(2 / 2)$ & & \\
\hline Fascin & $M$ & IPI00353563 & 54.3 & $3(2 / 2)$ & & $\mathrm{VV}[12]$ \\
\hline Fibronectin & $M$ & IPI00II3539 & 272.5 & $12(2 / 2)$ & & HIV-I [23]. \\
\hline $\begin{array}{l}\text { Guanine } \\
\text { nucleotide-binding } \\
\text { protein } \mathrm{G}(\mathrm{o}) \text {, alpha } \\
\text { subunit } 2\end{array}$ & $M$ & IPI00II 5546 & 39.9 & $2(3 / 2)$ & & \\
\hline Histone H3.2 & $M$ & IPI00230730 & 15.2 & $\mathrm{I}(2 / 2)$ & & \\
\hline \multirow[t]{2}{*}{ Histone $\mathrm{H} 4$} & $\mathrm{H}$ & IPI00453473 & 11.2 & $\mathrm{I}(2 / 2)$ & & $\begin{array}{l}\text { MMLV [25], HIV-I } \\
\text { [23], AIHV-I [I5], } \\
\text { SARS-CoV [22]. }\end{array}$ \\
\hline & $M$ & IPI00329998 & 11.4 & $\mathrm{I}(2 / 2)$ & & \\
\hline $\begin{array}{l}\text { Methyl-CpG- } \\
\text { binding domain } \\
\text { protein } 4\end{array}$ & $M$ & IPI0032I709 & 62.6 & $3(2 / 2)$ & & \\
\hline $\begin{array}{l}\text { Monocyte } \\
\text { differentiation } \\
\text { antigen CDI4 }\end{array}$ & $M$ & IPI00308990 & 39.2 & $3(3 / 2)$ & & HIV-I [23]. \\
\hline Pyruvate kinase & $M$ & IPI00407| 30 & 58.0 & $3(2 / 2)$ & & $\begin{array}{l}\text { Influenza [2I], } \\
\text { KHSV [20], HIV-I } \\
\text { [23], VV [I2,I3], } \\
\text { AlHV-I [15]. }\end{array}$ \\
\hline Integrin alpha-3 & $M$ & IPI00I26090 & $116.7 \mathrm{c}$ & & $12(7 / 5)$ & HIV-I [23]. \\
\hline Annexin $\mathrm{A} 3$ & M & IPI00I32722 & 36.2 & & $8(4 / 4)$ & \\
\hline Envelope protein & $M$ & IPI00406960 & 73.6 & & $7(6 / 4)$ & \\
\hline
\end{tabular}


Table I: Cellular proteins identified in purified virion preparations following I-D SDS-PAGE and LC-MS/MS (Continued)

\begin{tabular}{|c|c|c|c|c|c|}
\hline Basigin & M & IPI00II 3869 & 29.7 & $9(3 / 3)$ & HIV-I [23]. \\
\hline \multirow{2}{*}{$\begin{array}{l}\text { EH-domain- } \\
\text { containing protein } \\
\text { I }\end{array}$} & $\mathrm{H}$ & IPI000I7I84 & 60.6 & $9(3 / 3)$ & \\
\hline & $M$ & IPI00| 26083 & 60.6 & $9(3 / 3)$ & \\
\hline Gag protein & M & IPI00224370 & 60.3 & $7(4 / 3)$ & \\
\hline $\begin{array}{l}\text { Lymphocyte } \\
\text { antigen } 74\end{array}$ & M & IPI00II5558 & 35.0 & $8(3 / 3)$ & \\
\hline \multirow{2}{*}{$\begin{array}{l}\text { Tumor } \\
\text { susceptibility gene } \\
\text { I0I protein }\end{array}$} & $\mathrm{H}$ & IPI000I8434 & 43.9 & $9(3 / 3)$ & HIV-I [23]. \\
\hline & $M$ & IPI00II 7944 & 44.1 & $9(3 / 3)$ & \\
\hline $\begin{array}{l}\text { Acid } \\
\text { sphingomyelinase- } \\
\text { like } \\
\text { phosphodiesterase } \\
\text { 3b }\end{array}$ & M & IPI00II 7534 & 51.6 & $9(2 / 2)$ & \\
\hline Dystrophin & $M$ & IPI00474450 & 425.8 & $8(2 / 2)$ & \\
\hline \multirow{2}{*}{$\begin{array}{l}\text { Guanine } \\
\text { nucleotide-binding } \\
\text { protein } \mathrm{G}(\mathrm{I}) / \mathrm{G}(\mathrm{S}) / \\
\mathrm{G}(\mathrm{T}) \text { beta subunit }\end{array}$} & $\mathrm{H}$ & IPI00003348 & 37.2 & $8(3 / 2)$ & \\
\hline & $M$ & IPI00II6938 & 37.2 & $8(3 / 2)$ & \\
\hline $\begin{array}{l}\mathrm{H}-2 \text { class I } \\
\text { histocompatibility } \\
\text { antigen, D-D alpha } \\
\text { chain }\end{array}$ & M & IPI00II 0805 & 41.1 & $9(2 / 2)$ & \\
\hline $\begin{array}{l}\mathrm{H}-2 \text { class I } \\
\text { histocompatibility } \\
\text { antigen, L-D alpha } \\
\text { chain }\end{array}$ & M & IPI00I09996 & 40.7 & $9(2 / 2)$ & \\
\hline $\begin{array}{l}\text { L-lactate } \\
\text { dehydrogenase A } \\
\text { chain }\end{array}$ & $M$ & IPI003|9994 & 36.3 & $8(2 / 2)$ & $\begin{array}{l}\text { HCMV [19], VV } \\
\text { [I2], SARS-Cov } \\
\text { [22]. }\end{array}$ \\
\hline $\begin{array}{l}\text { Monocarboxylate } \\
\text { transporter I }\end{array}$ & $M$ & IPI00I37|94 & 53.3 & $8(2 / 2)$ & \\
\hline Myosin-9 & $\mathrm{H}$ & IPI000I9502 & 226.4 & $12(2 / 2)$ & VV [II], KHSV [20]. \\
\hline $\begin{array}{l}\text { T-complex protein } \\
\text { I subunit beta }\end{array}$ & $M$ & IPI00320217 & 57.3 & $9(2 / 2)$ & HIV-I [23]. \\
\hline $\begin{array}{l}\text { Transmembrane } \\
\text { protease, serine } \\
\text { IIE }\end{array}$ & $M$ & IPI00222870 & 50.0 & $9(2 / 2)$ & \\
\hline
\end{tabular}


Table I: Cellular proteins identified in purified virion preparations following I-D SDS-PAGE and LC-MS/MS (Continued)

\begin{tabular}{|c|c|c|c|c|c|}
\hline $\begin{array}{l}\text { Ubiquitin protein } \\
\text { ligase E3 } \\
\text { component } n \text { - } \\
\text { recognin } 4\end{array}$ & $M$ & $|\mathrm{PI} 0037868|$ & 572.3 & $8(2 / 2)$ & \\
\hline $\begin{array}{l}\text { 4F2 cell-surface } \\
\text { antigen heavy chain }\end{array}$ & $\mathrm{H}$ & IPI00027493 & $57.9 c$ & $17(9 / 7)$ & HIV-I [23]. \\
\hline Albumin & $\mathrm{H}$ & IPI00022434 & 71.7 & $14(3 / 3)$ & HIV-I [23]. \\
\hline Annexin Al & $\mathrm{H}$ & IPI002I89|8 & 38.6 & $14(3 / 3)$ & $\begin{array}{l}\text { Influenza [2I], } \\
\text { HCMV [19], VV } \\
\text { [II], HIV-I [23], } \\
\text { MCMV [I7], HSV-I } \\
\text { [I8], AIHV-I [I5]. }\end{array}$ \\
\hline CDI09 antigen & $\mathrm{H}$ & IPI00I52540 & 161.7 & $18(3 / 3)$ & \\
\hline $\begin{array}{l}\text { Transmembrane } \\
\text { protein } 2\end{array}$ & $\mathrm{H}$ & IPI00I70706 & 154.4 & $18(3 / 3)$ & \\
\hline Aminopeptidase $\mathrm{N}$ & $\mathrm{H}$ & IPI0022I 224 & 109.4 & $18(2 / 2)$ & $\begin{array}{l}\text { HIV-I [23], HCMV } \\
\text { [19]. }\end{array}$ \\
\hline \multirow[t]{2}{*}{ Integrin alpha-V } & M & IPI003|9509 & 109.5 & $18(2 / 2)$ & HIV-I [23]. \\
\hline & $\mathrm{H}$ & IPI00027505 & 116.0 & $18(2 / 2)$ & \\
\hline $\begin{array}{l}\text { Lutheran blood } \\
\text { group glycoprotein }\end{array}$ & $\mathrm{H}$ & IPI00002406 & $67.4^{c}$ & $17(2 / 2)$ & \\
\hline $\begin{array}{l}\text { Neutral amino acid } \\
\text { transporter } B(0)\end{array}$ & $\mathrm{H}$ & IPI000I9472 & $56.6^{c}$ & $17(2 / 2)$ & \\
\hline $\begin{array}{l}\text { Programmed cell } \\
\text { death } 6 \text { interacting } \\
\text { protein }\end{array}$ & $\mathrm{H}$ & IPI00246058 & 96.8 & $17(2 / 2)$ & $\begin{array}{l}\text { MMLV [25], HIV-I } \\
\text { [23]. }\end{array}$ \\
\hline $\begin{array}{l}\text { Ras-related protein } \\
\text { Rab-IIB }\end{array}$ & $M$ & IPI00I35869 & 24.3 & $13(2 / 2)$ & \\
\hline $\begin{array}{l}\text { Ras-related protein } \\
\text { Rap-IA }\end{array}$ & M & IPI00|38406 & 21.0 & $13(2 / 2)$ & HIV-I [23]. \\
\hline \multirow{2}{*}{$\begin{array}{l}\text { Solute carrier } \\
\text { family } 2 \text {, facilitated } \\
\text { glucose transporter } \\
\text { member I }\end{array}$} & $\mathrm{H}$ & IPI00220I94 & $54.1^{c}$ & $17(2 / 2)$ & \\
\hline & $M$ & IPI0030869I & $53.9 c$ & $17(2 / 2)$ & \\
\hline $\begin{array}{l}\text { T-complex protein } \\
10 \mathrm{a}\end{array}$ & $M$ & IPI00| 22340 & 47.1 & $18(3 / 2)$ & \\
\hline
\end{tabular}

a From search of human $(H)$ or mouse $(M)$ database

$\mathrm{b}$ International protein index accession numbers

c Glycosylated protein

d Gel bands were numbered as depicted in Figure 2D

e ASFV, African swine fever virus; AlHV-I, Alcelaphine herpesvirus-I; AcNPV, Autographa californica nuclear polyhedrosis virus; EBV, Epstein-Barr virus; HCMV, human cytomegalovirus; HIV-I, human immunodeficiency virus-I; KSHV, Kaposi's sarcoma-associated herpesvirus; MV, measles virus, MMLV, Moloney murine leukemia virus; MCMV, murine cytomegalovirus; NDV, Newcastle disease virus; RV, rabies virus; SeV, Sendai virus; SARS$\mathrm{CoV}$, severe acute respiratory syndrome coronavirus; SIV, simian immunodeficiency virus; VV, vaccinia virus 

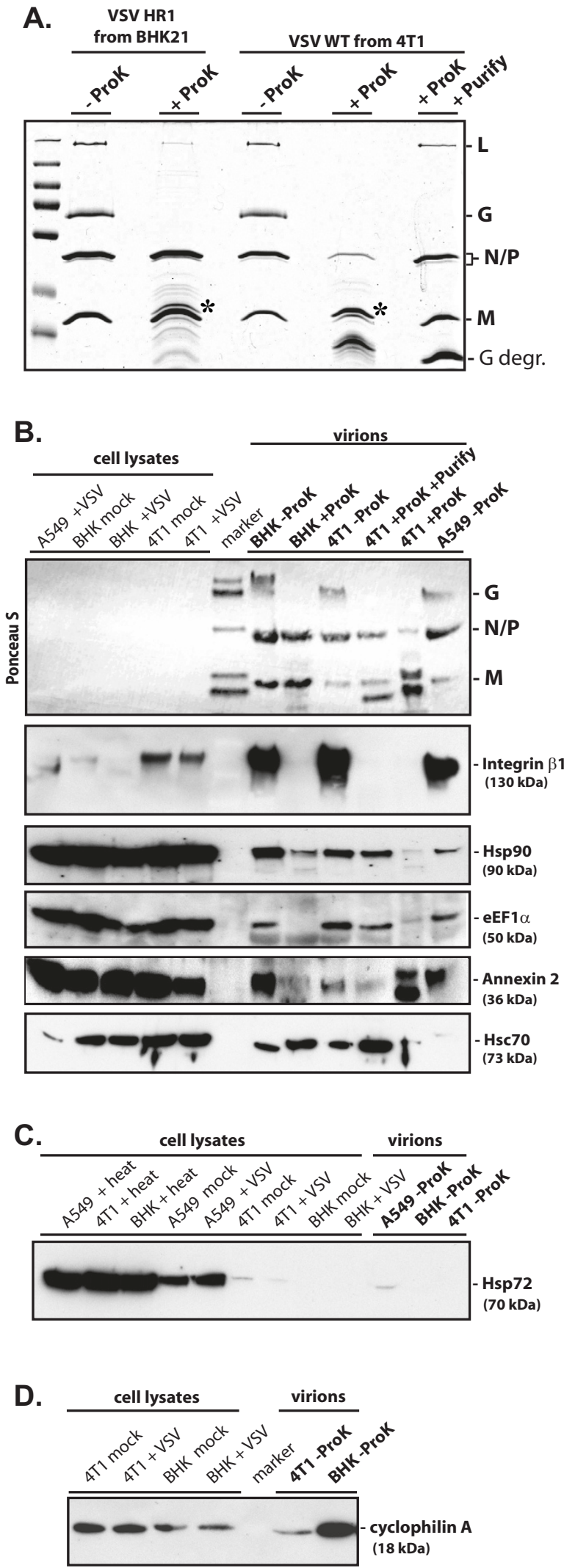

Figure 3

\section{Figure 3}

Verification of protein incorporation within the virion preparations. Purified virion preparations (shown in Figure 2A) were left untreated (-ProK) or were treated with Proteinase $\mathrm{K}$ (+ProK) for $\mathrm{I} .5 \mathrm{~h}$ at $37^{\circ} \mathrm{C}$ to remove all surface exposed proteins. Following ProK treatment, one 4TIderived virion sample was also centrifuged through a $20 \%$ sucrose gradient to remove ProK and free floating peptides (+ProK +Purify). (A) $5 \mu \mathrm{g}$ of total protein from untreated purified virions or the viral protein equivalent from the ProK treated samples were separated on a 10\% SDS-PAGE gel and stained with Coomassie Brilliant Blue R250. Asterisk indicates position of the ProK protein above the $M$ protein. $G$ degr., indicates VSV G protein fragment(s) generated as a result of ProK treatment. (B-D) Immunoblots were performed using $10 \mu \mathrm{g}$ cellular lysate from mock infected or VSV-wt (+VSV) infected cells harvested at $18 \mathrm{~h}$ p.i. or $10 \mu \mathrm{g}$ of heat shocked (+heat) cellular lysates harvested after a $4 \mathrm{~h}$ incubation at $43^{\circ} \mathrm{C}$, and $50 \mu \mathrm{g}$ of total protein from ProK treated or untreated purified virion preparations. Proteins were separated on gradient $8-16 \%$ (B and C) or I5\% SDSPAGE (D) gels, transferred to PVDF membranes and rapidly stained with the reversible dye Ponceau S prior to the use of antibodies to confirm levels of viral proteins (cellular proteins were not detectable). Primary antibodies were against integrin $\beta \mathrm{I}$, heat shock protein $90 \mathrm{kDa}(\mathrm{Hsp} 90)$, translation elongation factor I alpha (EFI $\alpha$ ), annexin 2, heat shock cognate $70 \mathrm{kDa}(\mathrm{Hsc} 70)$, stress-inducible $70 \mathrm{kDa}$ heat shock protein (Hsp72), and cyclophilin A, as indicated.

ProK-treated virions derived from 4T-1 cells without additional purification, so slightly less than $50 \mu \mathrm{g}$ of this virus was used for immunoblotting (Fig. 3A-B, sample 4T-1 + ProK).

The presence of integrin $\beta 1$, Hsp90, Hsc70, annexin 2 and EF1a in the virion preparations was confirmed by immunoblotting. With the exception of integrin $\beta 1$, all of the proteins could be detected in at least one of the ProK treated samples at levels similar to the untreated samples. The reason for the variable responses of the ProK treated samples is not known, however, the presence of a protein in the ProK treated and additionally purified VSV ("4T1+ProK+Purify" sample, Fig. 3A-B) would strongly indicate the presence of the protein within virions. This sample consistently showed a high level of protection of these proteins except for annexin 2 which can be located either intracellularly or on the extracellular membrane, and therefore a portion of it is likely vulnerable to ProK degradation [40]. In contrast, for integrin $\beta 1$, where the extracellular domain is expected to be outside of the viral membrane, the protein levels were greatly reduced in all proteinase $\mathrm{K}$ treated samples, as seen for the viral $\mathrm{G}$ protein. 
We also analyzed untreated virion samples for two proteins not detected by our MS analysis. The stress-inducible $70 \mathrm{kDa}$ heat shock protein 70 (Hsp72, also known as Hsp70 and HSPA1A), previously shown to enhance measles virus transcription [41,42] and determine measles neurovirulence in mice [43], was readily detectable by immunoblotting in lysates prepared from cells heat shocked at $43^{\circ} \mathrm{C}$ for $4 \mathrm{~h}$ (Fig. 3C). Without heat shock, Hsp72 was also easily detected in A549 lysates, weakly detected in 4T-1 lysates and not detected at all in BHK21 lysates. In keeping with this, Hsp72 could be detected in virions from A549 cells but was not seen in virions from $4 \mathrm{~T} 1$ or BHK21 cells. That Hsp72 was detected equally well in all the heat shocked lysates suggests these differences are not solely due to variable antibody recognition of Hsp72 from different sources. VSV infection did not appear to induce Hsp72 expression at the time point analyzed. Immunoblotting also confirmed the presence of cyclophilin A (Fig. 3D) in virions derived from BHK21 and $4 \mathrm{~T} 1$ cells (the A549 preparation was not tested for this protein).

\section{Discussion}

In this study, we conducted the first systematic study of the cellular protein composition of VSV virions. To compare host protein content of VSV virions across species and cell types, we analyzed virions isolated from three different cell types of human, mouse and hamster origin. In total, our analysis successfully identified all five VSV proteins as well as 64 cellular proteins (Table 1), plus keratins. For the majority of the identified proteins, the predicted molecular weight was consistent with the size range encompassed by the 1-D SDS-PAGE gel slice the protein was found in, which served as an additional confirmation of the cellular protein identity. However, the two groups of proteins, keratins (identified but not shown in Table 1) and ubiquitin (Table 1), were broadly distributed among the gel slices. Keratins are common environmental contaminants and their broad distribution among the gel slices without correlation to the predicted molecular weight suggests contamination as the primary source of the keratin peptides identified in our MS analysis. Ubiquitin was also detected across a wide range of molecular weights, suggesting that at least some viral and/or cellular proteins within VSV virions are ubiquitinated, although phospholipid anchored ubiquitin (not linked to any protein) has been found in the envelopes of several different viruses $[44,45]$. Further studies are needed to determine the functional role of ubiquitin association with VSV virions.

Of the 64 identified proteins, relatively few were identified in multiple samples originated from different cell sources. Five proteins [tubulin alpha, annexin A2, EF1a, ubiquitin and integrin $\beta 1$ ] were identified in all three samples while tubulin beta, cytoplasmic actin and translation elongation factor 2 were identified only in the BHK21 and 4T1 derived virion preparations; and transferin receptor protein 1 was identified only in the $4 \mathrm{~T} 1$ and A549 derived preparations. There are several possible explanations for this limited overlap including: (1) Limitations in the ability of MS to detect certain proteins, particularly those found in low abundance; (2) Differences in sample quality between the three preparations; (3) Cell specific differences in gene expression or virus assembly; (4) Some proteins of hamster origin (BHK21) potentially lack sufficient homology to be identified using the mouse or human databases used in this study.

Consistent with the first possibility, Hsp90 and Hsc70 were detected by MS only in the BHK21 derived virions. However, when examined by immunoblotting (Fig. 3B), Hsp90 was detected in all three virion preparations, and Hsc70 was detected in the BHK21 and 4T1 virion preparations (the antiserum did not react strongly with Hsc70 from A549, preventing any conclusion about this sample). Importantly, of the 64 proteins, 35 were identified on the basis of only two unique peptides while for other 14 proteins only three unique peptides were identified. All this suggests other proteins may also be present in multiple virion preparations despite being detected in only a single sample by MS.

In regard to the second possibility, the sample derived from BHK21 cells was primarily composed of particles readily recognizable as VSV, while the virion preparations from A549 and 4T-1 cells showed fewer intact virus particles and a large number of unwound VSV nucleocapids containing viral genomic RNA (Fig. 2A), and had a lower infectivity per $\mu \mathrm{g}$ of protein. Therefore, it is possible that some of the cellular proteins normally present within viral particles were "leaked out" during virus purification from A549 and 4T1 cells (accounting for their absence in those preparations). Furthermore, it is possible that some cellular proteins found in the A549 and 4T1 preparations are associated with free nucleocapsids rather than the virions. These differences in virion properties may have also impacted some of the other assays used in this study. For example, genome isolation may have been more efficient from the A549 and 4T1 samples, perhaps partially accounting for the higher number of genomes detected in these preparations. It may have also had an effect on the proteinase $\mathrm{K}$ assay as suggested by the fact that approximately $70 \%$ of the supposedly internal viral proteins were degraded when virions isolated from 4T1 cells were treated with proteinase $\mathrm{K}$ as opposed to approximately $50 \%$ for virions isolated from BHK21 cells.

The variability in proteins identified in the different virus preparations could also be due to cell specific differences 
in gene expression or virus assembly. An apparent example of the former is Hsp72 which has been shown to enhance measles virus transcription $[41,42]$ and is a determinant of measles neurovirulence in mice [43]. This protein was not specifically detected by our MS analysis although the closely related and constitutively expressed Hsc70 protein was identified (Table 1 and Figure 3), as were several peptides common to both Hsc70 and Hsp72. Upon heat shock, Hsp72 could be detected by immunoblotting in lysates from all three cell types, but in the absence of this stress, was easily detectable in A549 lysates, weakly detected in 4T1 lysates and not detected at all in BHK21 lysates. In keeping with this expression profile, Hsp72 could be detected only in virions from A549, demonstrating that, at least in some cases, host cell protein expression may affect incorporation of cellular proteins into virions.

Using a MS approach, this study confirmed the presence of several cellular proteins within VSV virions (tubulin [5], translation elongation factor 1 alpha [7], and Hsc70 [10]). However, we were unable to detect at least three proteins previously shown to be associated with VSV virions (cyclophilin A [6], cellular RNA guanylyltransferase [8], and casein kinase II [9]) as well as several proteins shown to bind individual VSV proteins including the beta and gamma subunits of elongation factor 1 [7] and heat shock protein 60 (Hsp60) [46]. Failure of our analysis to detect some of these proteins does not challenge their potential role in VSV replication, as these proteins may be present within the virions but were not detectable in our MS analysis, or, in the case of the protein interactions shown outside the virion, the described interactions may be transient. When two of our virus preparations were tested for the presence of cyclophilin A by immunoblotting, it was detected (Fig. 3D), demonstrating the list of proteins generated by our MS analysis is not entirely inclusive.

Due to the nature of a MS proteomics approach, it will be necessary to confirm the presence of the identified proteins within the VSV virion and their role is viral replication, as incorporation within the virion does not necessarily imply a functional significance. "Accidental" incorporation of cellular proteins is particularly likely to occur during virus budding as abundant cytosolic proteins can be trapped by the newly forming viral envelope and host proteins are not excluded from the membrane used to form the envelope. We have initiated this process for several proteins of potential interest whose presence in the virion has not previously been shown (Hsp90, actin, annexin 2 , and integrin $\beta 1$ ), by confirming their presence in our virion preparations by immunoblotting, and, for the non-membrane proteins, confirming their presence within the virion by proteinase K protection assay (Fig. 3B and data not shown).

Pharmacological inhibition of Hsp90 or its knockdown by siRNA has been shown to inhibit replication of several negative-strand RNA viruses including VSV but its presence within VSV virions was not previously investigated [47]. Actin has previously been shown to be incorporated into Sendai [48], measles [49] and rabies [50] virions but was not detected in VSV virions [50]. Here, using MS, we have shown actin to be present within VSV as well (Table 1). Annexins bind phospholipids in a calcium dependent manner and are believed to help direct membrane-membrane and membrane cytoskeleton interactions. In particular, annexin 2 has been proposed to facilitate HIV-1 assembly at cellular membranes [23]. Integrin $\beta 1$ forms heterodimers with various alpha integrins that function in both cell adhesion and cell signaling. While proteins found in multiple preparations may not be more important than those found only a single sample, the presence of annexin 2 and integrin $\beta 1$ in all three samples as well as in a number of other viruses (for example, integrin $\beta 1$ has also been detected in influenza, HIV-1 and Moloney murine leukemia virus), suggests that these two proteins may be involved in widely used viral processes (see far right column of Table 1 for complete listing and references). In fact, many of the cellular proteins identified in our study have been found in association with the virions of different RNA and DNA viruses (Table 1) suggesting that enveloped viruses may use similar cellular pathways for their assembly and exit from the cell. Currently, a similar study using a proteomics approach is being conducted in our laboratory to identify cellular proteins in virions of other members of the family Mononegavirales. Such comparative analysis will reveal how similar or different the cellular content of virions are among different members of this order.

\section{Conclusion}

In summary, this is, to our knowledge, the first systematic study of the host protein composition for virions of VSV (or any other member of the order Mononegavirales). We have successfully used a proteomic approach to confirm the presence of several cellular proteins within VSV virions and to identify a number of additional proteins likely to also be present within the virions, some of which may play an important role in VSV replication and possibly be involved in previously unconsidered pathways in the virus life cycle. However, we recognize the potential of proteins not associated with virions to persist in our preparations despite purification and that these would also be identified by a global proteomics approach. Additionally, the inclusion of a protein within the virion does not necessarily imply a functional significance. Therefore, future experiments are needed to determine which of the identi- 
fied proteins interact with VSV and whether these interactions are beneficial, neutral or antiviral with respect to VSV replication. Identification of host proteins-virus interactions beneficial for virus would be particularly exciting as they can provide new ways to combat viral infections via control of host components.

\section{Materials and methods Cells and viruses}

The following cell lines were used in this study: Syrian golden hamster kidney fibroblast cells (BHK21; ATCC\# CCL-10), mouse mammary gland adenocarcinoma cells (4T1; ATCC\# CRL-2539), and human epithelial lung carcinoma cells (A549; ATCC\# CCL-185). Monolayer cultures of these cell lines were maintained in Minimum Essential Medium (Eagle's MEM, Cellgro) or in Dulbecco's modified Eagle's medium (DMEM, Cellgro) supplemented with $9 \%$ fetal bovine serum (FBS, Gibco) in a $5 \% \mathrm{CO}_{2}$ atmosphere at $37^{\circ} \mathrm{C}$. Infectivity $(\mathrm{PFU} / \mathrm{ml})$ of virus stocks was calculated by standard plaque assay on BHK21 cells. To grow and purify viruses, cells were infected with wt or mutant VSV and incubated at $34^{\circ} \mathrm{C}$. BHK21 cells were infected with VSV HR1 at a multiplicity of infection (MOI) of 0.005, while A549 and 4T1 cells were infected with VSV wild type (VSV-wt, Indiana serotype) at an MOI of 0.1 and 0.5, respectively. VSV HR1 is a well characterized mRNA cap methylation defective VSV (Indiana serotype) mutant $[26,28,29]$ with a mutation in the $\mathrm{L}$ protein with a $\mathrm{D}$ to $\mathrm{V}$ substitution at position 1671 $[26,27]$. This mutation completely eliminates viral mRNA cap methylation at both the guanine-N7 and 2'-O-adenosine positions $[26,27]$ and results in subsequent nontranslatability of primary VSV transcripts in non-permissive cell lines [51-53]. As a result, VSV HR1 displays a host-range (hr) phenotype characterized by severely restricted growth in most cell types but only slightly delayed growth in a limited number of "permissive" cells including BHK21 cell line where it achieves wild type titers.

\section{Virus purification and protease treatment}

Virus containing media was collected at 20-28 hours (h) post infection (p.i.) when most cells were infected but significant cell detachment had not yet occurred (to maximize exclusion of cellular debris). The media was centrifuged at $3000 \times \mathrm{g}$ for 10 minutes $(\mathrm{min})$ to remove large cellular debris and then at $71,000 \times \mathrm{g}$ and $4{ }^{\circ} \mathrm{C}$ for 1 $\mathrm{h}$ in a Beckman SW32 Ti rotor to pellet the viral particles. The viral pellet was resuspended in ET buffer $(1 \mathrm{mM}$ Tris$\mathrm{HCl} \mathrm{pH} 7.5,1 \mathrm{mM}$ EDTA) with 10\% DMSO and centrifuged in a $7-60 \%$ discontinuous sucrose gradient composed of steps of $2 \mathrm{ml}$ of $60 \%(\mathrm{w} / \mathrm{w})$ sucrose, $3 \mathrm{ml}$ of $45 \%$ sucrose, $4.5 \mathrm{ml}$ of $25 \%$ sucrose and $1.5 \mathrm{ml}$ of $7 \%$ sucrose. Sucrose solutions were made in HEN buffer $(10 \mathrm{mM}$ HEPES pH 7.4, 1 mM EDTA, $100 \mathrm{mM} \mathrm{NaCl}$ ). Following centrifugation overnight at $130,000 \times \mathrm{g}$ and $4^{\circ} \mathrm{C}$ using a Beckman SW40 Ti rotor, the virus containing band was removed from the gradient and diluted with ET buffer. The virus was pelleted by centrifugation at $130,000 \times \mathrm{g}$ and $4{ }^{\circ} \mathrm{C}$ for $1 \mathrm{~h}$ using a Beckman SW40 Ti rotor and resuspended in ET/DMSO buffer. Viral titers were determined by standard plaque assay on BHK21 cells.

For protease treatment, purified virions from BHK21 and 4T1 cells were treated with $0.08 \mu \mathrm{g}$ proteinase $\mathrm{K}$ (ProK) per $1 \mu \mathrm{g}$ total protein. After $1.5 \mathrm{~h}$ incubation at $37^{\circ} \mathrm{C}$, phenylmethanesulphonylfluoride (PMSF) was added to a final concentration of $5 \mathrm{mM}$ and the samples were incubated on ice for $15 \mathrm{~min}$ to stop proteinase activity. A portion of the treated virions from 4T1 cells were also centrifuged through a $2 \mathrm{ml} 20 \%$ sucrose cushion at $173,000 \times \mathrm{g}$ and $4{ }^{\circ} \mathrm{C}$ for $2.5 \mathrm{~h}$ using a Beckman SW40 Ti rotor. The pelleted virus was resuspended in ET buffer.

\section{Electron microscopy}

Virions were absorbed to carbon-formvar coated grids (Electron Microscopy Sciences) by floating grids on $4 \mu \mathrm{l}$ drops of sample for $1 \mathrm{~min}$. Grids were blotted dry and stained with $2 \%$ uranyl acetate in water for 30 seconds. Excess stain was removed and the grids allowed to air dry. Samples were visualized using a Philips CM10 transmission electron microscope.

\section{Protein identification following ID-SDS-PAGE}

$50 \mu \mathrm{g}$ of total protein from each purified virion sample was separated on a 10\% SDS-PAGE gel, stained with Coomassie Brilliant Blue R250 and gel bands were cut out for analysis. Gel pieces were subjected to in-gel trypsin digestion and the resulting peptides were extracted from the gel matrix, separated using reverse-phase nano-liquid chromatography and analyzed by tandem MS as described previously [36]. Briefly, samples were separated by a 68 min linear gradient from $90 \%$ Solvent I $(0.1 \%$ formic acid in water)/Solvent II ( $0.1 \%$ formic acid in acetonitrile) to $50 \%$ Solvent I/II at a flow rate of $500 \mathrm{nl} / \mathrm{min}$ on reversed phase chromatography using a trap/elute method with a in-house $\mathrm{C}_{18}$ sample trap in line with a $\mathrm{C}_{18}$ analytical column. The spectra were searched using the SEQUEST algorithm of the Bioworks software (ThermoFisher, San Jose, CA; version SRF v. 3) against the IPI.HUMAN.v.3.18 and IPI.MOUSE.v.3.18 databases concatenated with a VSV protein database. A parent ion mass tolerance of $2.0 \mathrm{Da}$, fragment ion mass tolerance of $1.0 \mathrm{Da}$, and a $16 \mathrm{Da}$ differential modification for methionine oxidation were used for search parameters. Protein identifications were accepted when the peptide probability was greater than $95.0 \%$ [54], the protein probability was greater than $99.0 \%$, and contained at least 2 identified peptides. Scaffold software was used for data compiling of each group and calculating spectral count [55-57]. 


\section{Northern blot analysis}

Total RNA was extracted from purified virion samples containing $25 \mu \mathrm{g}$ of protein using the QIAamp viral RNA extraction kit (Qiagen), ethanol precipitated and resuspended in $30 \mu \mathrm{l}$ of RNase-free water. Half of this material was separated on a 1.5\% agarose-formaldehyde gel and transferred to a nylon membrane. Following blocking with hybridization buffer (Ambion) at $45^{\circ} \mathrm{C}$, the membrane was incubated overnight at $45^{\circ} \mathrm{C}$ in hybridization buffer containing $30 \mathrm{ng} / \mathrm{ml}$ of a 5'-biotinylated oligonucleotide complimentary to the first 55 nucleotides of the VSV genome (5'-biotinGATCCTTAAGACCCTCTTGTGGTTTTTATTTTTTATCTGGTTTTGTGGTCTTCGT-3'). Following blocking with TBS with $0.1 \%$ Tween 20 and 1\% non-fat milk powder at room temperature for $30 \mathrm{~min}$, the membrane was incubated with a streptavidin-horseradish peroxidase-conjugate in that same buffer for $1 \mathrm{~h}$. The Enhanced Chemiluminescence Plus (ECL+) protein detection system (GE Healthcare) was used for detection and the membrane was exposed to BioMax Light film (Kodak).

\section{Protein gel electrophoresis and immunoblot analysis}

Cellular lysates were prepared by mock infecting 4T-1, A549 and BHK cells or by infecting them with VSV-wt at MOIs of $0.5,0.1$ and 0.05 respectively. Cells were harvested at $18 \mathrm{~h}$ p.i. and lysed in RIPA buffer ( $25 \mathrm{mM}$ Tris$\mathrm{HCl}$ pH 7.6, 150 mM NaCl, 1\% NP-40, 1\% Sodium deoxycholate and $0.1 \%$ SDS). For heat shocked lysates, uninfected cells were incubated at $43^{\circ} \mathrm{C}$ for $4 \mathrm{~h}$ and immediately harvested. Protein concentrations of cellular lysates and purified virions were determined by Bradford assay. $50 \mu \mathrm{g}$ of purified virions and $10 \mu \mathrm{g}$ of cellular lysates were separated on gradient $8-16 \%$ or $15 \%$ SDSPAGE gels, transferred to PVDF membranes and rapidly stained with the reversible dye Ponceau $S$ prior to the use of antibodies to confirm levels of viral proteins and the quality of protein transfer from gel to membrane. Membranes were blocked in TBS $(0.5 \mathrm{M} \mathrm{NaCl}, 20 \mathrm{mM}$ Tris $\mathrm{pH}$ 7.5) with $0.1 \%$ Tween 20 and 5\% non-fat milk powder and then probed with antibodies against integrin $\beta 1(\mathrm{~N}$ 20; Santa Cruz Biotechnology), Hsp90 (68; BD Bioscience), EF1a (D-15; Santa Cruz Biotechnology), annexin 2 (H-50; Santa Cruz Biotechnology), Hsc70 (1B5; Assay Designs), Hsp72 (C92F3A-5; Assay Designs), or cyclophilin A (2175; Cell Signaling Technology). Detection was with species specific horseradish peroxidase-conjugated secondary antibodies using the Enhanced Chemiluminescence Plus (ECL+) protein detection system (GE Healthcare) and exposure to BioMax Light film (Kodak).

\section{Competing interests}

The authors declare that they have no competing interests.

\section{Authors' contributions}

MM conducted all experiments except for the MS analysis. SIH provided virion MS analysis and sequence matching to mouse and human databases. MM drafted the manuscript. MM and VZG edited the manuscript. VZG provided overall supervision, financial support and prepared the final version of the manuscript. All authors read and approved the final manuscript.

\section{Acknowledgements}

We are grateful to Sue Moyer (University of Florida College of Medicine) for providing VSV reagents for this project, Kimberly McKinney for technical assistance with the mass spectrometry, and the Carolinas Medical Center Electron Microscopy Facility for use of their electron microscope and for technical assistance and advice from David Radoff and Pat McCoy This work was supported by NIH Grants 5R03AI078I22 and IRI5GM084422 (to V. Z. G.).

\section{References}

I. Lamb RA, Parks GD: Paramyxoviridae: The viruses and their replication. In Fields Virology 5th edition. Edited by: Knipe DM, Howley PM. Lippincott Williams \& Wilkins, Philadelphia; 2007:I 449- 1496.

2. Lyles DS, Rupprecht CE: Rhabdoviridae. In Fields Virology 5th edition. Edited by: Knipe DM, Howley PM. Lippincott Williams \& Wilkins, Philadelphia; 2007:1363-1408.

3. Whelan SP, Barr JN, Wertz GW: Transcription and replication of nonsegmented negative-strand RNA viruses. Curr ToP Microbiol Immunol 2004, 283:6 I-I I9.

4. Cantin R, Methot S, Tremblay MJ: Plunder and stowaways: incorporation of cellular proteins by enveloped viruses. J Virol 2005 , 79:6577-6587.

5. Moyer SA, Baker SC, Lessard JL: Tubulin: a factor necessary for the synthesis of both Sendai virus and vesicular stomatitis virus RNAs. Proc Natl Acad Sci USA 1986, 83:5405-5409.

6. Bose S, Mathur M, Bates P, Joshi N, Banerjee AK: Requirement for cyclophilin $A$ for the replication of vesicular stomatitis virus New Jersey serotype. J Gen Virol 2003, 84:1687-1699.

7. Das T, Mathur M, Gupta AK, Janssen GM, Banerjee AK: RNA polymerase of vesicular stomatitis virus specifically associates with translation elongation factor- $I$ alphabetagamma for its activity. Proc Natl Acad Sci USA 1998, 95: |449-1454.

8. Gupta AK, Mathur M, Banerjee AK: Unique capping activity of the recombinant RNA polymerase (L) of vesicular stomatitis virus: association of cellular capping enzyme with the $L$ protein. Biochem Biophys Res Commun 2002, 293:264-268.

9. Gupta AK, Das T, Banerjee AK: Casein kinase II is the $\mathbf{P}$ protein phosphorylating cellular kinase associated with the ribonucleoprotein complex of purified vesicular stomatitis virus. $J$ Gen Virol 1995, 76:365-372.

10. Sagara J, Kawai A: Identification of heat shock protein $\mathbf{7 0}$ in the rabies virion. Virology 1992, 190:845-848.

II. Chung CS, Chen $\mathrm{CH}, \mathrm{Ho}$ MY, Huang CY, Liao CL, Chang W: Vaccinia virus proteome: identification of proteins in vaccinia virus intracellular mature virion particles. J Virol 2006, 80:2127-2140.

12. Manes NP, Estep RD, Mottaz HM, Moore RJ, Clauss TR, Monroe ME, Du X, Adkins JN, Wong SW, Smith RD: Comparative proteomics of human monkeypox and vaccinia intracellular mature and extracellular enveloped virions. J Proteome Res 2008, 7:960-968.

13. Resch W, Hixson KK, Moore RJ, Lipton MS, Moss B: Protein composition of the vaccinia virus mature virion. Virology 2007, 358:233-247.

14. Bortz E, Whitelegge JP, Jia Q, Zhou ZH, Stewart JP, Wu TT, Sun R: Identification of proteins associated with murine gammaherpesvirus 68 virions. J Virol 2003, 77: I3425-13432.

15. Dry I, Haig DM, Inglis NF, Imrie L, Stewart JP, Russell GC: Proteomic analysis of pathogenic and attenuated alcelaphine herpesvirus I. J Virol 2008, 82:5390-5397. 
16. Johannsen E, Luftig M, Chase MR, Weicksel S, Cahir-McFarland E, Illanes D, Sarracino D, Kieff E: Proteins of purified Epstein-Barr virus. Proc Natl Acad Sci USA 2004, I 0 I: 16286-16291.

17. Kattenhorn LM, Mills R, Wagner M, Lomsadze A, Makeev V, Borodovsky M, Ploegh HL, Kessler BM: Identification of proteins associated with murine cytomegalovirus virions. J Virol 2004, 78: III87-III 97.

18. Loret S, Guay G, Lippe R: Comprehensive characterization of extracellular herpes simplex virus type I virions. J Virol 2008, 82:8605-86/8

19. Varnum SM, Streblow DN, Monroe ME, Smith P, Auberry KJ, PasaTolic L, Wang D, Camp DG 2nd, Rodland K, Wiley S, et al: Identification of proteins in human cytomegalovirus (HCMV) particles: the HCMV proteome. J Virol 2004, 78: 10960-10966.

20. Zhu FX, Chong JM, Wu L, Yuan Y: Virion proteins of Kaposi's sarcoma-associated herpesvirus. J Virol 2005, 79:800-8II.

21. Shaw ML, Stone KL, Colangelo CM, Gulcicek EE, Palese P: Cellular proteins in influenza virus particles. PLoS Pathog 2008, 4:el000085.

22. Neuman BW, Joseph JS, Saikatendu KS, Serrano P, Chatterjee A, Johnson MA, Liao L, Klaus JP, Yates JR 3rd, Wuthrich K, et al.: Proteomics analysis unravels the functional repertoire of coronavirus nonstructural protein 3. I Virol 2008, 82:5279-5294.

23. Chertova E, Chertov O, Coren LV, Roser JD, Trubey CM, Bess JW Jr, Sowder RC 2nd, Barsov E, Hood BL, Fisher RJ, et al.: Proteomic and biochemical analysis of purified human immunodeficiency virus type I produced from infected monocytederived macrophages. / Virol 2006, 80:9039-9052.

24. Saphire AC, Gallay PA, Bark S): Proteomic analysis of human immunodeficiency virus using liquid chromatography/tandem mass spectrometry effectively distinguishes specific incorporated host proteins. J Proteome Res 2006, 5:530-538.

25. Segura MM, Garnier A, Di Falco MR, Whissell G, Meneses-Acosta A Arcand N, Kamen A: Identification of host proteins associated with retroviral vector particles by proteomic analysis of highly purified vector preparations. J Virol 2008, 82: I I07-I I I 7.

26. Grdzelishvili VZ, Smallwood S, Tower D, Hall RL, Hunt DM, Moye SA: A single amino acid change in the L-polymerase protein of vesicular stomatitis virus completely abolishes viral mRNA cap methylation. J Virol 2005, 79:7327-7337.

27. Grdzelishvili VZ, Smallwood S, Tower D, Hall RL, Hunt DM, Moyer $S A$ : Identification of a new region in the vesicular stomatitis virus $L$ polymerase protein which is essential for mRNA cap methylation. Virology 2006, 350:394-405.

28. Horikami SM, De Ferra F, Moyer SA: Characterization of the infections of permissive and nonpermissive cells by host range mutants of vesicular stomatitis virus defective in RNA methylation. Virology 1984, I38: I-I5.

29. Simpson RW, Obijeski JF: Conditional lethal mutants of vesicular stomatitis virus. I. Phenotypic characterization of single and double mutants exhibiting host restriction and temperature sensitivity. Virology 1974, 57:357-368.

30. McSharry J], Wagner RR: Lipid composition of purified vesicular stomatitis viruses. J Virol | 97I, 7:59-70.

31. McCombs RM, Melnick MB, Brunschwig JP: Biophysical studies of vesicular stomatitis virus. I Bacteriol |966, 91 :803-812.

32. Finke S, Brzozka K, Conzelmann KK: Tracking fluorescencelabeled rabies virus: enhanced green fluorescent proteintagged phosphoprotein $P$ supports virus gene expression and formation of infectious particles. J Virol 2004, 78: I 2333-12343.

33. Brouillette CG, Compans RW, Brandts JF, Segrest JP: Structural domains of vesicular stomatitis virus. A study by differential scanning calorimetry, thermal gel analysis, and thermal electron microscopy. J Biol Chem 1982, 257:12-15.

34. Orenstein J, Johnson L, Shelton E, Lazzarini RA: The shape of vesicular stomatitis virus. Virology 1976, 71:291-301.

35. Arstila P. Characteristics of vesicular stomatitis virus envelopes released with saponin. J Gen Virol 1974, 24:319-326.

36. Hwang SI, Lundgren DH, Mayya V, Rezaul K, Cowan AE, Eng JK, Han DK: Systematic characterization of nuclear proteome during apoptosis: a quantitative proteomic study by differential extraction and stable isotope labeling. Mol Cell Proteomics 2006, 5: I | $31-1 \mid 45$

37. Denard J, Rundwasser S, Laroudie N, Gonnet F, Naldini L, Radrizzani M, Galy A, Merten OW, Danos O, Svinartchouk F: Quantitative proteomic analysis of lentiviral vectors using 2-DE. Proteomics 2009, 9:3666-3676.

38. Betakova T, Nermut MV, Hay AJ: The NB protein is an integral component of the membrane of influenza B virus. J Gen Virol 1996, 77:2689-2694.

39. Ott DE, Coren LV, Kane BP, Busch LK, Johnson DG, Sowder RC 2nd, Chertova EN, Arthur LO, Henderson LE: Cytoskeletal proteins inside human immunodeficiency virus type I virions. I Virol 1996, 70:7734-7743.

40. Gerke V, Moss SE: Annexins: from structure to function. Physiol Rev 2002, 82:33I-37I.

4I. Parks CL, Lerch RA, Walpita P, Sidhu MS, Udem SA: Enhanced measles virus cDNA rescue and gene expression after heat shock. J Virol 1999, 73:3560-3566.

42. Vasconcelos DY, Cai XH, Oglesbee MJ: Constitutive overexpression of the major inducible $70 \mathrm{kDa}$ heat shock protein mediates large plaque formation by measles virus. J Gen Virol 1998, 79:2239-2247.

43. Carsillo T, Traylor Z, Choi C, Niewiesk S, Oglesbee M: hsp72, a host determinant of measles virus neurovirulence. J Virol 2006, 80: II031-II039.

44. Guarino LA, Smith G, Dong W: Ubiquitin is attached to membranes of baculovirus particles by a novel type of phospholipid anchor. Cell 1995, 80:30I-309.

45. Webb JH, Mayer RJ, Dixon LK: A lipid modified ubiquitin is packaged into particles of several enveloped viruses. FEBS Lett 1999, 444:136-139.

46. Qanungo KR, Shaji D, Mathur M, Banerjee AK: Two RNA polymerase complexes from vesicular stomatitis virus-infected cells that carry out transcription and replication of genome RNA. Proc Natl Acad Sci USA 2004, I O I:5952-5957.

47. Connor JH, McKenzie MO, Parks GD, Lyles DS: Antiviral activity and RNA polymerase degradation following Hsp90 inhibition in a range of negative strand viruses. Virology 2007, 362:109-119.

48. Lamb RA, Choppin PW: Determination by peptide mapping of the unique polypeptides in Sendai virions and infected cells. Virology 1978, 84:469-478.

49. Tyrrell DL, Norrby E: Structural polypeptides of measles virus. J Gen Virol 1978, 39:219-229.

50. Naito S, Matsumoto S: Identification of cellular actin within the rabies virus. Virology 1978, $91: 15 \mathrm{I}-163$.

51. Hercyk N, Horikami SM, Moyer SA: The vesicular stomatitis virus $L$ protein possesses the mRNA methyltransferase activities. Virology 1988, 163:222-225.

52. Horikami SM, Curran J, Kolakofsky D, Moyer SA: Complexes of Sendai virus NP-P and P-L proteins are required for defective interfering particle genome replication in vitro. I Virol 1992, 66:490I-4908.

53. Horikami SM, Moyer SA: Host range mutants of vesicular stomatitis virus defective in in vitro RNA methylation. Proc Natl Acad Sci USA 1982, 79:7694-7698.

54. Keller A, Nesvizhskii Al, Kolker E, Aebersold R: Empirical statistical model to estimate the accuracy of peptide identifications made by MS/MS and database search. Anal Chem 2002, 74:5383-5392.

55. Sadygov RG, Eng J, Durr E, Saraf A, McDonald H, MacCoss MJ, Yates JR 3rd: Code developments to improve the efficiency of automated MS/MS spectra interpretation. J Proteome Res 2002, I:2I I-2I5.

56. Yates JR 3rd, Eng JK, McCormack AL: Mining genomes: correlating tandem mass spectra of modified and unmodified peptides to sequences in nucleotide databases. Anal Chem 1995, 67:3202-3210.

57. Yates JR 3rd, McCormack AL, Link AJ, Schieltz D, Eng J, Hays L: Future prospects for the analysis of complex biological systems using micro-column liquid chromatography-electrospray tandem mass spectrometry. Analyst 1996, 12 I:65R-76R.

58. Esteves A, Marques MI, Costa JV: Two-dimensional analysis of African swine fever virus proteins and proteins induced in infected cells. Virology 1986, 152:192-206.

59. Wright JF, Kurosky A, Pryzdial EL, Wasi S: Host cellular annexin II is associated with cytomegalovirus particles isolated from cultured human fibroblasts. J Virol 1995, 69:4784-4791.

60. Ott DE, Coren LV, Johnson DG, Kane BP, Sowder RC 2nd, Kim YD, Fisher RJ, Zhou XZ, Lu KP, Henderson LE: Actin-binding cellular 
proteins inside human immunodeficiency virus type I. Virology 2000, 266:42-5I.

61. Cimarelli A, Luban J: Translation elongation factor I-alpha interacts specifically with the human immunodeficiency virus type I Gag polyprotein. J Virol I999, 73:5388-540I.

62. Ott DE, Coren LV, Copeland TD, Kane BP, Johnson DG, Sowder RC 2nd, Yoshinaka Y, Oroszlan S, Arthur LO, Henderson LE: Ubiquitin is covalently attached to the $\mathrm{p} 6 \mathrm{Gag}$ proteins of human immunodeficiency virus type I and simian immunodeficiency virus and to the $\mathrm{p} / 2 \mathrm{Gag}$ protein of Moloney murine leukemia virus. J Virol 1998, 72:2962-2968.

63. Jensen ON, Houthaeve T, Shevchenko A, Cudmore S, Ashford T, Mann M, Griffiths G, Krijnse Locker J: Identification of the major membrane and core proteins of vaccinia virus by two-dimensional electrophoresis. J Virol 1996, 70:7485-7497.

64. Vanderplasschen A, Mathew E, Hollinshead M, Sim RB, Smith GL: Extracellular enveloped vaccinia virus is resistant to complement because of incorporation of host complement control proteins into its envelope. Proc Natl Acad Sci USA 1998, 95:7544-7549.

65. Gurer C, Cimarelli A, Luban J: Specific incorporation of heat shock protein $\mathbf{7 0}$ family members into primate lentiviral virions. J Virol 2002, 76:4666-4670.

Publish with Bio Med Central and every scientist can read your work free of charge

"BioMed Central will be the most significant development for disseminating the results of biomedical research in our lifetime. "

Sir Paul Nurse, Cancer Research UK

Your research papers will be:

- available free of charge to the entire biomedical community

- peer reviewed and published immediately upon acceptance

- cited in PubMed and archived on PubMed Central

- yours - you keep the copyright 